Małgorzata Cackowska

https://doi.org.26881/ae.2018.15.05

ORCID: 0000-0002-6855-4646

Uniwersytet Gdański

caca@ug.edu.pl

\title{
Czego chce Basia od polskiego społeczeństwa?
}

Celem artykułu jest analiza i krytyka reprezentacji przestrzeni życiowych współczesnego dziecka zawartych w cieszącej się niezwykłą popularnością polskiej serii książek obrazkowych o życiu codziennym małej dziewczynki o imieniu Basia. Dokonano w nim charakterystyki wizerunku jej domu rodzinnego jako przestrzeni znaczącej dla rozwoju młodego człowieka w jej kulturowych, społecznych i politycznych aspektach, doprowadzając do próby odpowiedzi na pytanie o to, czego ten (tak popularny) przekaz chce od odbiorców, od polskiego społeczeństwa? Tytułowe pytanie jest trawestacją tytułu książki Czego chca obrazy? autorstwa jednego z najwybitniejszych badaczy i teoretyków kultury wizualnej Williama J.T. Mitchella, który analizuje w niej rozmaite relacje współczesnych widzów do obecnych w obrazach przedstawień i reprezentacji, badając kondycję dzisiejszego odbiorcy (Mitchell 2015). Krytyczne w konkluzji podejście do analizowanej w tekście serii książek spowodowane jest dostrzeżeniem fenomenu dużego zasięgu politycznie jednostronnej siły reprodukcji wzorców w nich obecnych.

Wybór serii ponad trzydziestu książek obrazkowych ${ }^{1}$ poświęconych codziennemu życiu współczesnej małej, rezolutnej dziewczynki autorstwa Zofii Staneckiej z ilustracjami Marianny Oklejak ${ }^{2}$ jako przedmiotu analizy tematycznie silnie związanej z doświadczeniem domu, zamieszkałych przestrzeni i organizacji życia rodzinnego, podyktowany był przede wszystkim pytaniem o przyczyny niebywałej ich popularności w populacji dzieci i rodziców (szczególnie matek) w małych

\footnotetext{
${ }^{1}$ Książki powstają od 2008 roku do dziś. Początkowo publikowano je w wydawnictwie LektorKlett, parę lat temu dzieło to przejęło wydawnictwo Egmont Polska - jedno z większych wydawnictw korporacyjnych. Każda z książek jest zatytułowana Basia i... - (jakiś) rzeczownik, określenie osoby lub miejsca akcji, z którymi związany jest epizod, na przykład Basia i mama w pracy, Basia i telefon, Basia i wolność, Basia i basen, Basia i dentysta itd.

${ }^{2}$ Pisarka i artystka należą do młodego pokolenia wybitniejszych polskich przedstawicielek twórczości dla dzieci.
} 
i wielkich miejscowościach. Wydawca podaje, że dotąd sprzedano ponad 500 tys. egzemplarzy serii o Basi, a inne źródła mówią, że rocznie sprzedaje się ich około 100 tys. Jest to dość wysoka liczba jak na polskich odbiorców kupujących książki dla dzieci, zważywszy na to, że życie książki dziecięcej nie kończy się u nabywcy. Popularność tej rodzimej produkcji dorównuje światowemu bestsellerowi kanadyjskiej serii o Franklinie autorstwa Paulette Bourgeois z ilustracjami Brendy Clark, a także może jeszcze bardziej popularnej belgijskiej serii o Martynce, kierowanej głównie do dziewczynek, autorstwa Gilberta Delahaye’a z ilustracjami Marcela Marliera. Książeczki o Basi, podobnie jak te serie, przedstawia uniwersum dziecięcych doświadczeń, jednak one nie mają walorów produkcji artystycznej, a raczej przybrały postać produkcji masowej i znacznie się różnią pod względem jakości graficznej i treściowej. Wyrazistą protoplastką Basi zdaje się dziewczynka znana polskim odbiorcom jako Zuzia, niemieckim zaś - w oryginale - Conni, przedstawiona w wydawanej przez Media Rodzina serii „Mądra Mysz - Zuzia” około czterdziestu broszurowych książek obrazkowych. Książki te, bardzo popularne w Niemczech od początku lat dziewięćdziesiątych ubiegłego wieku, stworzyła Liane Schneider w wymiennej współpracy z dwoma ilustratorkami: Evą Wenzel-Bürger i Annette Steinhauer. Można nawet sądzić, że zamysł wydawniczy serii o Basi jest wprost zapożyczony z serii o Conni (zob. il. 1).

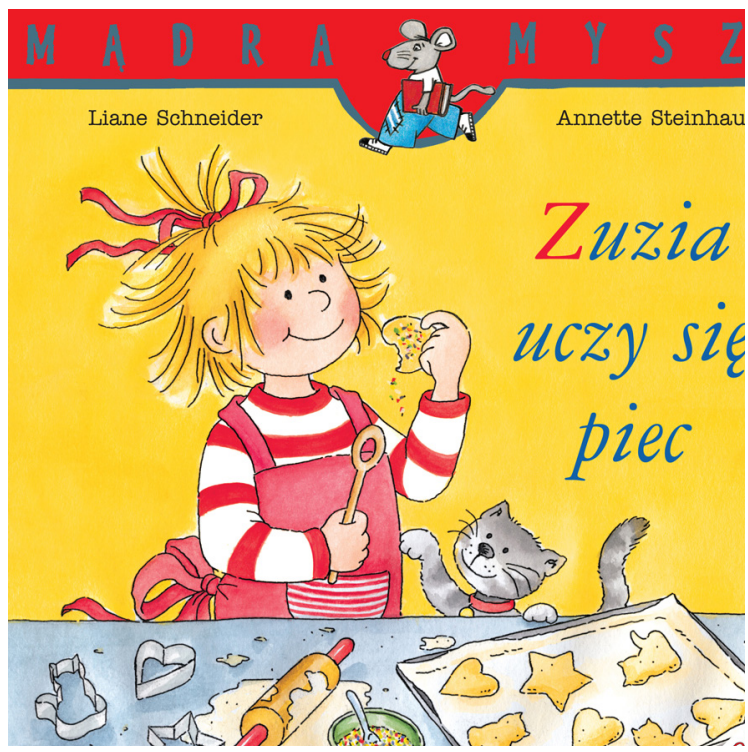

Il. 1. Okładka książki Zuzia uczy się piec autorstwa Liane Schneide ilustrowanej przez Anette Stenchauer z 2012 roku

Cykl oddzielnych, dwudziestoczterostronicowych książek obrazkowych o Basi został zainicjowany jedenaście lat temu jako polski produkt, który ma być rozpoznawalny przez polskich odbiorców. Z czasem seria o Basi przybrała jednak postać 
produkcji totalnej ${ }^{3}$, w której bohaterka jest postacią nie tylko serii książek, ale także zeszytów edukacyjnych z ćwiczeniami, filmów, gier (zob. Sikorska-Celejewska 2010). Dziś Basia występuje także w serii audiobooków, zeszytów Basia uczy do działań z liczeniem, pisaniem i czytaniem, kolorowaniem itp., przeznaczonych dla dzieci przedszkolnych, książeczek z naklejkami Poznaj Basię stanowiących skróconą i interaktywną wersję wybranych oryginałów, a także cyklu małych kartonowych książeczek konceptowych dla jeszcze młodszych dzieci w cyklu Basia, Franek i... (Franek to młodszy brat Basi) z krótką narracją dotyczącą codziennych spraw malucha typu: pielucha, zasypianie, ubieranie, ale też kolory, samochody. Powstały również zbiory opowiadań (na przykład Wielka ksiegga Basi, Wielka księga Basi i Franka) zawierające epizody z życia Basi i jej rodziny, wcześniej publikowane $\mathrm{w}$ „Mamo, to ja” - bardzo poczytnym miesięczniku dla młodych mam. Ponadto jest także: tabletowa wersja książki Basia i słodycze, gra planszowa Basia. Łap kolory, kilkuodcinkowy film animowany oraz liczne pomoce do pracy z dziećmi $\mathrm{w}$ domu i przedszkolu ( $\mathrm{w}$ tym scenariusze dla nauczycieli i bibliotekarzy). W sklepie wydawnictwa można też zamówić kubek z wizerunkiem bohaterki. Autorki serii cieszą się niesłabnącą popularnością podczas spotkań autorskich mających performatywny charakter, prowadzonych często w bardzo małych miejscowościach. Są znacznie lepiej rozpoznawane wśród dzieci i rodziców niż inni artyści funkcjonujący w polskim obiegu.

Każda książka o życiu Basi jest pomyślana jako oddzielna całość, wyczerpująca podjęty temat (problem), który nie ma kontynuacji w kolejnych częściach i da się ją zrozumieć bez czytania pozostałych pozycji serii (zob. il. 2).

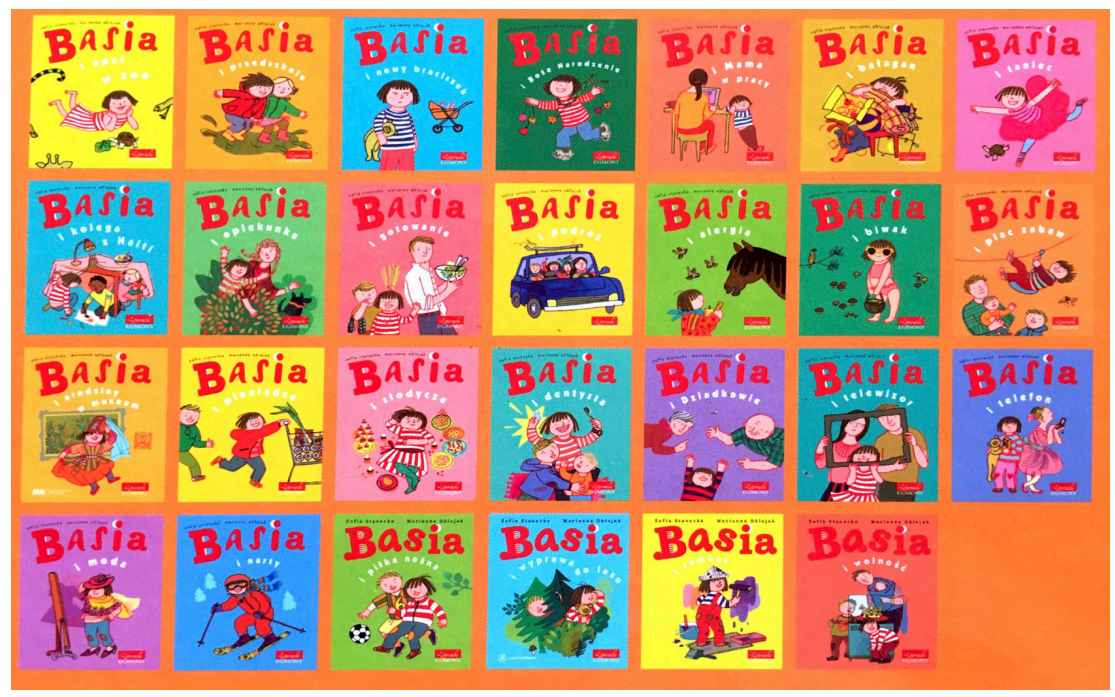

Il. 2. Seria książek obrazkowych o Basi, fotografia z tylnej okładki

${ }^{3}$ Szeroko o fenomenie produktu totalnego w sferze produkcji kulturowej dla dzieci pisze Michał Zając (2000). 
Życie Basi i jej rodziny jest jednak rozciągnięte w czasie (trwa od lata jednego roku i dzieje się w niemal całym roku następnym ${ }^{4}$ ). Dobrze jest podjąć wyzwanie czytania kolejno ukazujących się epizodów, aby poznać ten mikrokosmos dokładniej. Serię rozpoczęło jednoczesne wydanie czterech książek: Basia $i$ upał w zoo, Basia i przedszkole, Basia i nowy braciszek oraz Basia i Boże Narodzenie, dzięki czemu można było od razu dość dobrze poznać charakter pięcioletniej bohaterki, całą jej najbliższą rodzinę i dom. $Z$ treści samego tekstu wszystkich tych epizodów dowiadujemy się w zasadzie kluczowych rzeczy o realnej rzeczywistości bohaterki, o tym, że w lecie mama o imieniu Tosia jest w ciąży, a tato intensywnie pracuje jako lekarz w szpitalu. Basia mieszka w dużym mieście, w którym jest szpital i zoo (skąd przywozi do domu żółwia Kajetana), ma brata Janka i późną jesienią rodzi się maleńki Franek (wobec którego Basia przeżywa ambiwalentne emocje), lubi chodzić do przedszkola, w którym zaprzyjaźnia się z dziwaczną nieco koleżanką Anielką. Ma też babcie i dziadków (ich imion nie znamy, a dopiero w części Basia i dziadkowie domyślimy się, że są rodzicami mamy, ponieważ rodzice taty mieszkają daleko). W domu rodzinnym jest kuchnia, spiżarnia, łazienka, pokój Janka, pokój Basi, posiadają samochód. Rodzina jest religijna i celebruje tradycyjne święto chrześcijańskie (czytają fragmenty Biblii, jedzą tradycyjne potrawy i śpiewają kolędę katolicką Bóg się rodzi).

Tyle można dowiedzieć się z tekstu. W książce obrazkowej jednak, zwłaszcza dla małych dzieci, jest on raczej tylko kanwą dla zobrazowania istotnych składowych dla wyobrażenia pełni życia bohaterów. Tę funkcję pełni ilustracja, która w ogromnej mierze dopełnia całość przekazu. Na niej widzimy, że rodzina Basi mieszka na typowym osiedlu, $w$ dwu- lub trzypiętrowym ${ }^{5}$ bloku z dziesięcioma mieszkaniami, na ostatnim piętrze (zob. il. 3, na której życie rodzinne podglądamy z zewnątrz) w Warszawie (czego można się domyśleć po projekcie oznakowania bloku charakterystycznym dla stolicy).

Na ilustracjach widzimy, że w ich mieszkaniu są jeszcze dwa pokoje - w jednym znajduje się łóżeczko Franka (to sypialnia rodziców, co w pełni można zobaczyć dopiero w książce Basia $i$ bałagan) drugi to salon, a w nim fotele oraz sofa jako ważne miejsca życia rodziny ${ }^{6}$. W mieszkaniu jest również przestronny przedpokój oraz otwarta na salon kuchnia, która jest centralnym miejscem życia rodziny (w niej widać głównie stół). To ilustracja jest głównym nośnikiem informacji o wyglądzie bohaterów; z niej wiemy, że mama ma ciemne włosy, nosi okulary; Basia ma również ciemne włosy, piegi i bardzo często występuje w bluzce w biało-czerwone paski; tato i Janek mają włosy jasne, Janek jest niewiele większy od Basi (tym samym domyślamy się, że jest nieco starszy od bohaterki - il. 4). Dziewczynka

\footnotetext{
${ }^{4} \mathrm{~W}$ zamyśle twórców projektu i wydawcy jest zatrzymanie się na sprawach pięcioletniej bohaterki i nietowarzyszenie w jej dalszym rozwoju ze względu na docelowych odbiorców. Innymi słowy Basia nigdy nie dorośnie.

${ }^{5}$ Tego nie umie wskazać również ilustratorka (Sikorska-Celejewska 2010).

${ }^{6}$ Choć prawdziwe znaczenie sofy czytelnik poznaje dopiero w dalszej w serii książce - Basia igotowanie.
} 
ma pluszowego misia, z którym zazwyczaj się nie rozstaje - przytula się do niego lub jest w bliskim jej otoczeniu.

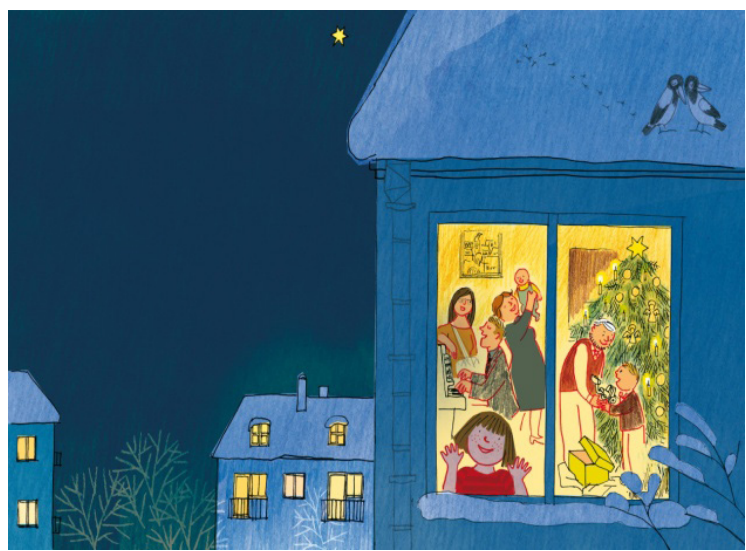

Il. 3. Ilustracja autorstwa Marianny Oklejak z książki Basia i Boże Narodzenie Zofii Staneckiej z 2009 roku
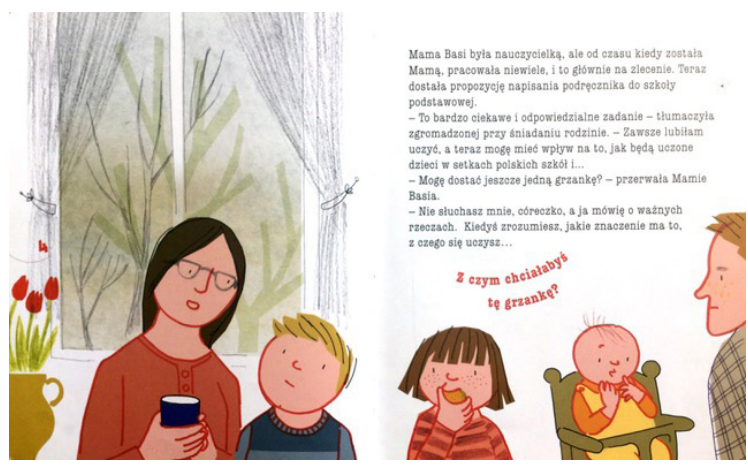

Il. 4. Ilustracja autorstwa Marianny Oklejak z książki Basia i mama w pracy Zofii Staneckiej z 2011 roku

By spróbować odnaleźć odpowiedź na pytanie zawarte w tytule tekstu, w dalszej części dokładniej przyjrzymy się zatem głównie obrazowym reprezentacjom najbliższych, ogniskowych i pedagogicznych przestrzeni życiowych Basi i jej rodziny, czyli tych znaczących miejsc, w których Basia uczy (się) życia (Mendel 2006).

\section{Basia i jej życiowe miejsca}

Na podstawie analizy wszystkich książek serii można stwierdzić, że najbardziej uwypuklono w nich miejsca, w których życie domowników jest gorące, intensywne i odgrywają kluczową rolę w doświadczeniu bohaterki, nabywaniu przez nią samoświadomości i tożsamości, w jej zadomowieniu. Są to: przede wszystkim kuchnia 
(a w niej stół jako centralne miejsce), pokój Basi (a w nim najważniejsze jej łóżko), salon (w nim sofa i fotele, książki). Opozycja do tych ognisk życia domowego rodziny Basi to zidentyfikowane $w$ toku analizy licznie zobrazowane reprezentacje nie-miejsc, które są ważnymi przestrzeniami w doświadczeniu nie tylko bohaterki, ale również dla odbiorców książek z tej serii. Choć książki pomyślane są tak, by w każdej z nich przedstawiać różnorodne, uniwersalne problemy i aspekty realiów codzienności (słodycze, dentysta, moda, remont, biwak, basen itp.), to w każdej $\mathrm{z}$ nich centralne miejsce pełni dom rodzinny tytułowej bohaterki. W niemal każdej książce (z wyjątkiem dwóch - Basia i biblioteka - gdzie akcja dzieje się w przedszkolu, w drodze do biblioteki, do której dzieci idą całą grupą, i w samej bibliotece oraz Basia $i$ alergia - która opowiada historię podczas pobytu całej rodziny w górach) reprezentacje domu, sceny życia rodzinnego, miejsca zamieszkania znajdują się na co najmniej dwóch (na jedenaście w każdej książce) rozkładówkach (na przykład w Basia i basen, który to epizod dotyczy wypoczynku na basenie, ale większość sytuacji rozgrywa się w domu bohaterki). Tam zaś, gdzie podjęty temat dotyczy sprawy z istoty rodzinnej (na przykład Basia i mama w pracy), wszystkie niemal sceny ukazują mieszkanie Basi.

\section{Kuchnia i stół}

Kuchnia w domu Basi jest sercem życia rodzinnego. Pojawia się w większości (17/30) książkowych epizodów, to w niej najczęściej przebywają lub przedstawieni są domownicy. W kuchni wybrzmiewają najmocniejsze emocje (kłótnia rodziców podglądana przez Basię przez uchylone drzwi korytarza), kuchnia staje się też miejscem różnych aktywności innych domowników (karmienie Franka, praca mamy, naprawianie przez tatę tostera). Tu znajduje się najbardziej znaczące miejsce tego domu - stół widoczny z salonu. Sam stół, przy którym jest choćby jeden domownik w znaczącej akcji lub wykonujący wymowny gest, pojawia się aż 39 razy. To przy nim toczą się najważniejsze rozmowy i zapadają ważne decyzje (to przy śniadaniu mama oznajmia rodzinie, że rozpoczyna pracę $\mathrm{w}$ domu, a tuż po posiłku siada do kuchennego blatu lub stołu, by zacząć pisać podręcznik metodyczny dla nauczycieli, innym razem zapada decyzja o wyjeździe na wakacje lub o remoncie). Stół w domu Basi ma kształt prostokąta, ale pomimo kultywowania tradycjonalistycznych wartości w tej rodzinie zajmowane przez domowników miejsca przy stole nie mają hierarchii, często siadają przy nim przypadkowo, co świadczyć może o dzieciocentrycznym podejściu rodziców i odchodzeniu od tradycyjnego przydziału miejsc (il. 5).

Stół to przede wszystkim miejsce wspólnego posiłku codziennego, a czasem uroczystego i świątecznego, a także miejsce wspólnego przygotowywania jedzenia (wykrajanie pierniczków, przygotowywanie przez Basię, Janka i tatę kolacji). Przy stole pokazywane są również przykre lub negatywne emocje (stęsknieni Basia, 
Janek i tata czekają na powrót mamy ze szpitala, innym razem Janek wścieka się, że ktoś - to była Basia - ukradł mu piłkarską kartę kolekcjonerską).

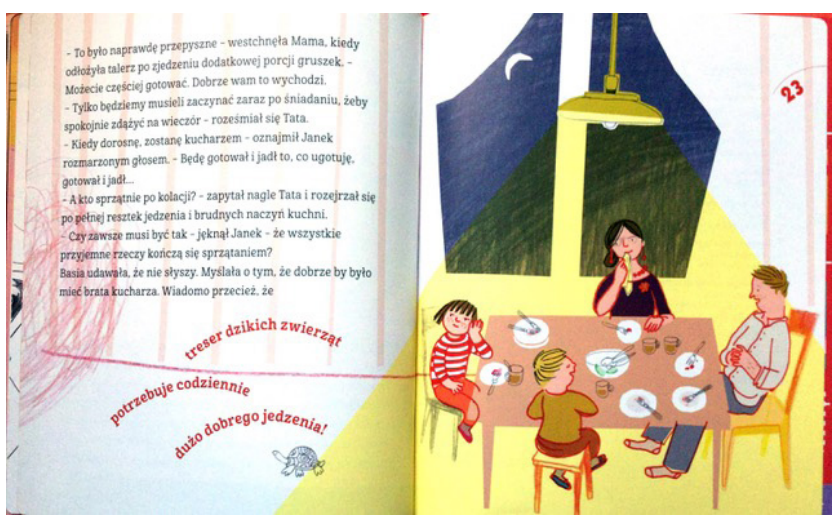

Il. 5. Ilustracja autorstwa Marianny Oklejak z książki Basia i gotowanie Zofii Staneckiej z 2011 roku

Stół bywa też miejscem ćwiczenia się Basi w samodzielności (zjada śniadanie, podczas gdy wszyscy jeszcze śpią) albo też doświadczania autonomicznej głębszej refleksji, gdy po zbyt intensywnym „słodyczowym” dniu wstaje w nocy, by przysiąść, wypić szklankę wody i zjeść kiszonego ogórka. Pod stołem Basia potrafi także znaleźć miejsce do rysowania, by być jak najbliżej rodziców.

\section{Pokój Basi - łóżko}

Pokój bohaterki ma - podobnie jak kuchnia - w serii wysoką frekwencję (16/29). W pokoju Basi zwykle panuje względny porządek (z wyjątkiem wspomnianej sytuacji z książki Basia i bałagan). Jest także kilku współmieszkańców, ale najważniejszym współlokatorem pokoju (i także wspólnikiem łóżka) jest jej ukochany Misiek-Zdzisiek, personifikowany pluszak, który często bierze udział w zabawie. W swym pokoju Basia najczęściej wyraża emocje: albo w odreagowującej, projekcyjnej zabawie (gdy pracująca w domu mama poprosiła Basię o nieprzeszkadzanie, ta trenuje Miśka-Ździśka), albo w dziękczynnym uścisku taty, który przynosi dziewczynce naprawioną pozytywkę.

Kluczowym miejscem ekspresji emocji bohaterki jest jednak łóżko. W nim przykrywa się kołdrą i zalewa łzami w sytuacji zazdrości o uwagę jej rodziców, gdy w domu pojawia się maleńki Franek, albo gdy zachorowała i jest głęboko nieszczęśliwa, ponieważ z tego powodu nie pojedzie do dziadków. Innym razem dzieli się z mamą swym zachwytem nad nową opiekunką bądź śni przecudny sen o wymarzonym telefonie. W łóżku marzy o słodyczach, a następnie wścieka się, gdy po przebudzeniu zdaje sobie sprawę, że to była mrzonka. Innym razem budzi 
się szczęśliwa, ponieważ nadchodzi dzień, w którym w przedszkolu zapowiedziana jest wycieczka do parku i na plac zabaw.

Drzwi pokoju Basi często bywają uchylone lub otwarte, szczególnie wtedy, gdy Basia nie ma izolacyjnych potrzeb.

\section{Salon, sofa, fotele}

Salon, choć zwykle bywa centralnym miejscem wielu współczesnych domów, w serii o Basi i jej rodzinie ma mniejszą reprezentację (11/29). Jest dla nich przede wszystkim miejscem wypoczynku, czasem zabawy, wspólnej aktywności mamy z Basią lub rozmowy na ważny temat w intymnym zaciszu fotela i pełni funkcję źródła emocjonalnego ciepła (na przykład gdy mama tłumaczy Basi, jak kataklizmy przyrodnicze na ziemi zmieniają życie ludzi). Sofę najczęściej zajmuje tata (bardzo zmęczony po nocnym dyżurze) i dzieci, szczególnie gdy mają potrzebę (bardzo rzadko w całej serii) oglądania telewizji. Telewizor nie jest $\mathrm{w}$ tej rodzinie niczym ważnym i rzadko pochłania uwagę domowników (jeden epizod - Basia $i$ telewizor jest jemu wprawdzie poświęcony w całości, ale koncentruje się na zgubnych skutkach oglądania przez małe dziecko nieodpowiedniego programu, dodatkowo w ostateczności psuje się, dzięki czemu Basia wymyśla świetną zabawę) (zob. il. 6).

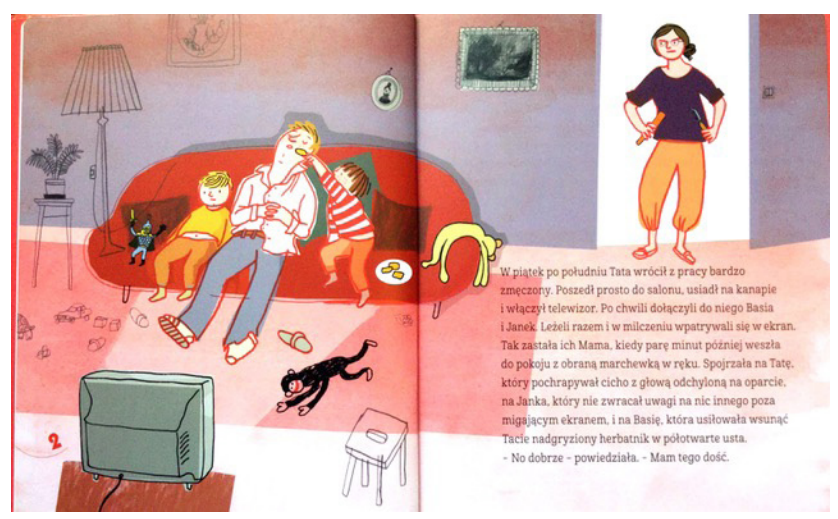

Il. 6. Ilustracja z książki Basia i gotowanie

$\mathrm{Na}$ ścianach wiszą różne obrazy (m.in. przypominający rynek Kazimierza miasteczka ukochanego przez warszawiaków) oraz portrety różnych osób, stoi pianino, na którym potrafi grać tato Basi, przy jednym z foteli, w którym zasiadają najczęściej rodzice, stoi pojemnik na gazety, a w nim są widoczne tygodniki. W salonie ważną funkcję reprezentacyjną pełni regał, na którym znajdują się dzieła klasyki polskiej i światowej; na półkach jest między innymi album Ermitaż (zapisany cyrylicą) oraz niewielki zbiór klasyki literatury światowej - Homer, Platon i polskiej - widoczne Potop Sienkiewicza i dzieła Potockiego (i wiele więcej nieczytelnych tytułów); są też albumy z fotografiami i schowki na pamiątki. W salonie 
stoi także stoliczek pod skromnym sprzętem grającym, na którym wnikliwy obserwator odnajdzie to, jakiej muzyki słucha się w domu Basi. Są tam: West Side Story, z polskich - wokalistka Violetta Villas słynna w latach sześćdziesiątych i siedemdziesiątych i jeszcze bardziej oldskulowy Jerzy Połomski. Ten duży pokój często przekształca się w plac świetnej zabawy inicjowanej przez Basię (domek z krzeseł dla Basi i Franka pokryty kapą lub występy w telewizji, gdy popsuł się odbiornik TV), a czasem w salę taneczną dla całej rodziny. Wszystkie te obiekty domowe dookreślają status społeczno-ekonomiczny tej rodziny - $\mathrm{z}$ ich pomocą można się upewnić, że są niezbyt zamożną klasą średnią (o czym świadczy widoczne skromne wyposażenie mieszkania i jakość sprzętów), ale reprezentują typ rodziny inteligenckiej o znaczącym kapitale kulturowym (książki, płyty z pola dystynktywnej kultury wysokiej).

\section{Nie-miejsca}

Marc Augé w swojej koncepcji określa nie-miejsca jako charakterystyczne dla hipernowoczesności przestrzenie tranzytywne, niczyje, ponieważ liczni ludzie, którzy w niej przebywają, nie mają z nią emocjonalnej więzi, jak również nie są powiązani ze sobą nawzajem. Są to na przykład supermarkety, dworce, przestrzenie wypoczynkowe (Augé 2012). Tych przestrzeni w książce jest najmniej (6/29) i - jak wspomniano - stanowią antypody domowego ogniska, opozycję do domu. Jednakże zostały tak mistrzowsko przedstawione na ilustracjach, że ukazują się w życiu Basi jako doświadczenia ważne, rozszerzają jej wiedzę o świecie, szczególnie o życiu społecznym i swej w nim roli, stąd należy im się chwila uwagi.

W przedstawianiu nie-miejsc ujawnia się także niezwykły talent obserwatorski Marianny Oklejak, która w ilustracji potrafi ukazywać i podkreślać rolę drugiego i każdego kolejnego planu, stosując sylleptyczą ${ }^{7}$ relację do tekstu. Zdradza też wyjątkowy dowcip, który pozwala jednak te zimne przestrzenie ocieplić (na przykład śmieszna nazwa supermarketu: „Mega Mag”). Basia poznaje typowe nie-miejsca, między innymi strefę wodnego wypoczynku, stację benzynową, supermarket spożywczo-przemysłowy, market budowlany, mall handlowy z całą charakterystyczną ich strukturą i porządkiem przemieszczania się, tymczasowością i zawieszeniem w czasie, który jednak dziewczynka często pożytkuje na dowolną zabawę (zob. il. 7).

Dzięki artystce $\mathrm{w}$ przedstawieniach tych nie-miejsc jest sporo mikronarracji, dzięki którym w skomercjalizowanej, z gruntu anonimowej i tłumnej przestrzeni uważny obserwator będzie mógł jednak odnaleźć człowieka (pańcia z dryblasem,

\footnotetext{
${ }^{7}$ Maria Nikolajeva i Carole Scott sylleptyczną określają taką relację obrazu i tekstu, w której dwie narracje lub więcej są niezależne od siebie, poboczne narracje rozchodzące się w różnych kierunkach stają się znaczące w całym przedstawieniu, mają różne znaczenia (Nikolajeva, Scott 2001: 12). W omawianym przypadku rzecz dotyczy oryginalnego kreowania przez artystkę drobnych historyjek na ilustracjach.
} 
zagubiony, samotny malec i wiele innych). Basia doświadcza tych przestrzeni jako swoistego eksperymentarium, w którym można się bawić, wykorzystując obiekty z ekspozycji (kręci z Jankiem kurkami, wchodzą do kabin prysznicowych, siadają na sedesach, innym razem jeżdżą na wózku, ślizgają się na mokrych kafelkach). Tym dość typowym dla dziecka sposobem oswaja je wbrew wyraźnemu dystansowi zmęczonej nimi mamy, która znalazła się tam w bardzo konkretnym celu.

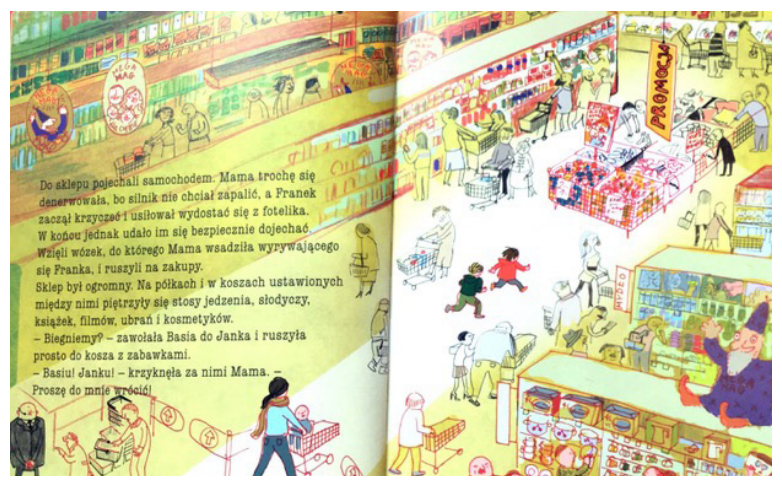

Il. 7. Ilustracja autorstwa Marianny Oklejak z książki Basia i pieniądze Zofii Staneckiej z 2011 roku

Zanalizowany tu obraz domu i wizerunku współczesnej rodziny z małymi dziećmi, przestrzeni ich życia, miejsc, w których są u siebie, dzięki którym czują się bezpiecznie, i nie-miejsc, z którymi zderzają się niemal codziennie, skłania badacza książki obrazkowej do zapytania jeszcze o to, czego ten przekaz chce od nas, od polskiego społeczeństwa ${ }^{8}$.

Medium kulturowe, jakim jest książka obrazkowa, ma charakter dyskursywny - jej celem jest oddziaływanie na odbiorców (dzieci i dorosłych), wpływanie na postawy i zachowania. Michael W. Apple i Linda K. Christian-Smith (1991) w rozważaniach nad refleksami kultury i stosunkami społecznymi w książkach, w tym także dla dzieci, podkreślają, że utwór nie jest niewinnym medium służącym jedynie łatwej rozrywce, ale nade wszystko jest znaczącym nośnikiem idei i ideologii. Dla dzieci jest ona medium szczególnym, dociera bowiem do dziecięcej wyobraźni nie tyle przez słowa, co głównie przez obrazy. W przypadku książek o świecie Basi - jak pokazano niejednokrotnie - obrazy potrafią tak współtworzyć przekaz, że często mówią o wiele więcej niż słowa. Nie jest zatem bez znaczenia, jaki świat książka obrazuje, zwłaszcza gdy dzięki sile serii odnosi się do szerokiego uniwersum możliwego doświadczenia, napędzając ogromną popularność wśród dorosłych odbiorców, pokoleń młodych, niewprawnych i niepewnych w swych nowych rolach rodziców.

${ }^{8} \mathrm{~W}$ przypadku wspomnianej niemieckiej serii książek o Conni można by tak samo zapytać o jego znaczenie w tym społeczeństwie. Sądzę, że odpowiedzi byłyby zbliżone, mimo - albo nawet tym bardziej - że społeczeństwo niemieckie jest zróżnicowane kulturowo, a Conni jest typową reprezentantką niemieckiej klasy średniej. 
Żeby móc w pełni odpowiedzieć na pytanie, czego chce Basia, z pewnością trzeba głębiej zanalizowaći pokazać znacznie więcej aspektów życia dziewczynki i jej rodziny, szczególnie tych bardziej znaczących, jak sposoby komunikacji, postawy i praktyki rodziców wobec pojawiających się w każdym $\mathrm{z}$ epizodów problemów związanych z codziennym życiem rodzinnym i społecznym. Język ich porozumiewania się pełni bardzo ważna funkcję w całym zamyśle edukacyjnym książek. Jest to kod rozwinięty, wypowiedzi dorosłych i dzieci zawierają argumentację, elementy perswazji, asertywności i ekspresję emocji. Zdania wypowiadających się są zwykle przemyślane, pełne i stanowią wyrazisty i jasno skierowany na cel komunikat, mocno przypominający język coachingu. Styl tego kodu wyraźnie domaga się głębszej analizy, szczególnie ze względu na wskazywaną tu popularność serii, głównie wśród młodych rodziców. Jedyną krytyczną refleksję poświęconą jakości literackiej tego tekstu znajdziemy w krótkim felietonie Karoliny Felberg-Sendeckiej. Autorka dosadnie komentuje nadmierny w serii domowy coaching, „arcyśredniość" bohaterów i ich problemów, codzienne formatowanie bohaterów i czytelnika. Nade wszystko przeraża ją matka Basi, „która mówi do własnych dzieci językiem posthumanistycznym i zachowuje się jak cyborg, tudzież przedszkolanka, u której przedawkowano coaching" oraz to, że obecna $\mathrm{w}$ wielu domach taka lektura nie budzi pytań dzieci (Felberg-Sendecka 2017: 22-23)9. Nie sposób nie zgodzić się z tą opinią, zwłaszcza w przypadku książki obrazkowej, w której warstwa i narracja wizualna pozwala zebrać odbiorcy (szczególnie dziecku, które samo jeszcze nie czyta) jeszcze więcej istotnych informacji charakteryzujących bohaterów, ich styl i jakość życia. Przyjrzenie się zaledwie jednemu aspektowi - domowi i zamieszkałym przestrzeniom - i tak pozwala na wyprowadzenie poniższych spostrzeżeń.

Seria o Basi jest - na podobieństwo katechezy - przekazem głoszącym świadectwo wartościowego życia ludziom nieco pogubionym w nowoczesności opartej na ekonomii neoliberalnej. Przypomina, że rodzina (ze znaczącą, tradycyjną trójką dzieci) i dom są miejscem uświęconym, miejscem wykuwania się tożsamości wspólnotowej $\mathrm{i}$ indywidualnej. Pokazuje, że w przestrzeniach domu rodzina musi spędzać ze sobą wszystkie możliwe chwile (najwięcej przy stole), a rodzice powinni poświęcać dzieciom bardzo wiele czasu. Rodzice Basi reprezentują elitarną klasę średnią z rezerwuarem kapitału kulturowego: mają wyższe wykształcenie i dość prestiżowy zawód (tata lekarz, mama była nauczycielka, aktualnie pracuje $\mathrm{w}$ domu, pisząc poradniki metodyczne dla nauczycieli), mają inteligenckie pochodzenie (ich rodzice są architektami, lekarzami). Swym stylem życia ujawniają wyraźną tendencję do bycia rodziną tradycyjną (rytualne codzienne i odświętne zogniskowanie przy stole, kultywowanie świąt religijnych), dystansują się wobec dóbr materialnych (skromne samo mieszkanie, jak i jego wyposażenie, dystans do nowych technologii, zwłaszcza w użytkowaniu przez dzieci), ale pielęgnują swój zmaterializowany kapitał kulturowy (posiadają i eksponują spore zasoby klasyki literatury i albumy sztuki światowej i polskiej). Rodzina

${ }^{9} \mathrm{~W}$ Polsce krytyka literacka jest bardzo oszczędna wobec mainstreamowych publikacji dla dzieci liczących się na rynku wydawców. 
żyje zakorzeniona w swoim miejscu (domu-mieszkaniu) i zdaje się być w nim szczęśliwa. Osadzeni są w przestrzeni wielkiego miasta, w którym do koniecznych nie-miejsc (związanych z konsumpcją, komercją) rodzice ujawniają wyraźny dystans, przekazując go dzieciom. Rodzina Basi nie ma nazwiska, rodzice dziewczynki nie są w każdym calu idealni i konsekwentni, dzięki czemu stanowią familiarny, możliwy do zasymilowania, swojski, ale na wskroś dystynktywny wzorzec.

Mówiąc językiem teorii reprodukcji kulturowej, ten symboliczny, konserwatywny i elitarny wzorzec życia rodzinnego przyciąga współczesnych rodziców aspirujących do miana klasy średniej, którzy dysponując zaledwie kapitałem ekonomicznym, poszukują nobilitującego mechanizmu legitymizacji swojej pozycji oraz prestiżu i stabilizacji swego statusu (Bourdieu, Passeron 2011). Dzięki serii o Basi mogą czuć się upełnomocnieni i ten schemat życia skutecznie odtwarzać. Na licznych blogach parentingowych można znaleźć wypowiedzi, głównie młodych matek, zachwyconych rodzicami Basi. Pragną się z nimi identyfikować, wprost mówią, jak uczą się (zwłaszcza od mamy Basi) organizacji domu i życia rodzinnego, wychowywania (formatowania) dzieci, jakim językiem mówić do pociech, by te ich słuchały. Dzieje się to jednak w poczuciu mocowania się w ogromnym napięciu i dysonansie ze zgoła innymi pragnieniami posiadania i eksponowania swego nabytego dorobku, nastawienia na siebie i chęcią pokazywania zupełnie innego stylu życia "na bogato". To charakterystyczna dla klasy średniej dążącej do awansu dwoistość świata społecznego.

W zjawisku niezwykłej popularności prostych, choć nie zawsze oczywistych w swym przekazie książek o Basi można uchwycić symptom społecznych problemów aktualizujących się w przyjmowanej przez klasę średnią polskiego społeczeństwa dramatycznie rosnącej (ir)racjonalności opartej na wybuchowej mieszance wartości konserwatywnych i wolnorynkowych. $\mathrm{Ci}-\mathrm{w}$ ogromnej mierze młodzi rodzice (nabywcy serii) - łatwo zdają się porzucać pragnienie autentycznej wolności i jeszcze łatwiej poddawać się zniewoleniu politycznej manipulacji. W Basi przyglądają się sobie, utwierdzają $\mathrm{w}$ jedynie słusznym, odtwarzalnym wyborze przewidywalnego średniego stylu życia. W książkach o Basi z uwewnętrznionym przekonaniem pokazują swym dzieciom świat wzorcowych relacji społecznych, podporządkowania, (samo)dyscypliny, (samo)uznania. Tego chyba właśnie chce Basia...

\section{Literatura}

Apple M.W., Christian-Smith L.K., 1991, The Politics of the textbook [w:] The Politics of the Textbook, eds M.W. Apple, L.K. Christian-Smith, New York: Routledge.

Augé M., 2012, Nie-miejsca. Wprowadzenie do antropologii hipernowoczesności, tłum. R. Chymkowski, Warszawa: Wydawnictwo Naukowe PWN.

Bourdieu, P., Passeron J.C., 2011, Reprodukcja. Elementy teorii systemu nauczania, tłum. E. Neyman, Warszawa: Wydawnictwo Naukowe PWN.

Felberg-Sendecka K., 2017, Literatura jak coach, czyli ja i mój wróg, „Opowiadanie”, nr 6, http://opowiadanie.org/wp-content/uploads/2017/10/Opowiadanie_6_Net.pdf [dostęp: 2.11.2018]. 
Mendel M. (red.), 2006, Pedagogika miejsca, Wrocław: Wydawnictwo Naukowe Dolnośląskiej Szkoły Wyższej Edukacji TWP.

Mitchell, W.J.T., 2015, Czego chca obrazy?, tłum. Ł. Zaremba, Warszawa: Narodowe Centrum Kultury.

Nikolajeva M., Scott C., 2001, How Picturebooks Work, New York-London: Routledge.

Sikorska-Celejewska A., 2010, Basia się spodobała i pomaszerowała w świat... - rozmowa z Zofia Stanecką i Marianną Oklejak, Qlturka.pl, http://qlturka.pl/2015/12/08/basia-sie-spodobala-i-pomaszerowala-w-swiat-rozmowa-z-zofia-stanecka-i-marianna-oklejak/ [dostęp: 15.07.2017].

Zając M., 2000, Promocja książki dziecięcej: podręcznik akademicki, Warszawa: Wydawnictwo Stowarzyszenia Bibliotekarzy Polskich.

\section{Materiały źródłowe:}

Bourgeois P., Clark B., 2003-, „Franklin” (seria), tłum. P. Zarawska, Katowice: Wydawnictwo Debit.

Delahaye G., Marliera M., 1993-, „Martynka” (seria), tłum. A. Woroniecki, Poznań: Wydawnictwo Publicat.

Schneider L., Stenchauer A., 2012, Zuzia uczy się piec, tłum. E. Kledzik, Poznań: Wydawnictwo Media Rodzina.

Stanecka Z., Oklejak M., 2008-, „Basia” (seria), Warszawa: Wydawnictwo Egmont Literacki.

\section{Streszczenie}

W artykule przedstawiono analizę i krytykę reprezentacji przestrzeni życiowych współczesnego dziecka w niezwykle popularnej polskiej serii książek obrazkowych o codziennym życiu małej dziewczynki Basi. Artykuł opisuje obraz jej domu rodzinnego jako przestrzeni, która ma znaczenie dla rozwoju młodego człowieka w jego kulturowych, społecznych i politycznych aspektach, i próbuje odpowiedzieć na pytanie, czego ten (bardzo popularny) przekaz chce od swoich czytelników, od polskiego społeczeństwa? Pytanie pojawiające się w tytule jest trawestacją tytułu książki What Do Pictures Want? Williama J.T. Mitchella, jednego z najwybitniejszych badaczy i teoretyków kultury wizualnej, który analizował różne relacje między współczesną publicznością a reprezentacjami obecnymi w obrazach, poszukując wiedzy o kondycji współczesnego odbiorcy (Mitchell 2015).

Podsumowując, krytyczne podejście do serii książek analizowanych w tekście wynika z wrażliwości na dostrzeżenie fenomenu szerokiego zakresu politycznie jednostronnej siły reprodukcji modeli zawartych w książkach.

\section{Słowa kluczowe}

książka obrazkowa, reprodukcja kulturowa, klasa średnia, polskie społeczeństwo 


\section{Summary}

What does Basia want from the Polish society?

This paper presents an analysis and critique of the representation of living spaces of the contemporary child in the hugely popular Polish series of picturebooks on the daily life of a little girl called Basia. The article describes the image of her family home primarily as a space which is significant for the development of a young person in its cultural, social, and political aspects, and finally tries to answer the question of what this (very popular) message wants from its readers, the Polish society? The question appearing in the title is a travesty of the title of the book What Do Pictures Want? by William J.T. Mitchell, one of the most eminent researchers and theoreticians of the visual culture, who analysed various relations between the contemporary audience and representations present in images, searching for knowledge on the condition of today's viewer (Mitchell 2015).

In conclusion, the critical approach to the series of books analysed in the text derives from sensitivity to noticing the phenomenon of a large range of politically unilateral power of reproduction of the models the books contain.

\section{Keywords}

picturebook, cultural reproduction, middle class, Polish society 